\title{
Morphophysiological Evaluation of Schizolobium Parahyba \\ Var. Amazonicum and Eucalyptus urograndis Growing in Different Levels of Shading
}

\author{
Hygor Gomes de Almeida Sousa ${ }^{1}$ (c) \\ Igor Viana Souza ${ }^{1}$ \\ Bruno Aurélio Campos Aguiar ${ }^{1}$ \\ Gabriella Rayssa Antunes da Silva Oliveira ${ }^{1}$ \\ Flávia Bezerra Souza ${ }^{1}$ \\ Maristela Lima Figueiredo Guimarães Epifânio ${ }^{1}$ \\ Valéria Cardoso Lopes ${ }^{1}$ \\ Priscila Bezerra Souza ${ }^{1}$ \\ ${ }^{1}$ Universidade Federal do Tocantins, Gurupi, TO, Brasil.
}

\begin{abstract}
This study aimed to identify the best shade level for the growth of Schizolobium parabyba var. amazonicum and Eucalyptus urograndis seedlings to obtain more resilient seedlings with higher quality. We used an entirely randomized design was used, in a $2 \times 4$-factor scheme, with two species and four levels of shading, comprising 5 repetitions and 6 plants per repetition, totaling 30 plants per treatment. The four shading levels were characterized as follows: T1 (full sun), T2 (50\%-shading screen), T3 (plastic), T4 (50\%-shading screen plus wool blanket). For the production of Eucalyptus urograndis seedlings, it is recommended an unshaded environment, since one variable showed a significant difference. For the Schizolobium parahyba var. amazonicum species, it is suggested to produce it under shade, where is was achived ( $50 \%$ together with the wool blanket), better results for the most variables.
\end{abstract}

Keywords: Environment, Growth, Forest-planted, Primary material.

\section{INTRODUCTION AND OBJECTIVES}

Especially in the last decades, there has been progress in Brazilian forestry concerning forest improvement, cultural treatments, especially for the exploitation of wood with fast growth and annual increment (Malagi, 2015).

The Brazilian forestry sector has shown good numbers of planted forests, leading the country to the spotlight of the international scenario, with a total of 7.83 million ha in 2018 , practically stable when compared to 2017 . However, the certified area increased to 6.3 million ha, including both productive and certificated areas (Ibá, 2019).

In accordance with Ibá (2019), there are 90,811 hectares of Schizolobium parahyba var. amazonicum planted in Brazil, which grows about 20 to $30 \mathrm{~m}^{3} / \mathrm{ha} /$ year, being similar to species such as pine, with 25 to $30 \mathrm{~m}^{3} / \mathrm{ha}$ /year, then exceeding Tectona grandis with 15 to $20 \mathrm{~m}^{3} / \mathrm{ha} /$ year. Its fast growth contributes to the species reaching great heights in a short time, and presents a silvicultural and technological potential to be used in activities aimed at reforestation (Vidaurre, 2012).

Since the very start of its cultivation, the Eucalyptus urograndis has provided great homogenization to planted forests and, because of this, it is currently cultivated in 600,000 ha (Xavier, 2013). Therefore, when compared to other conventional species, it can be $15 \%$ higher than conventional species. This hybrid is adapted to nearly all regions of the country, except for the south, since it is considered sensitive to severe frost (Bentec, 2020). In this sense, the Eucalyptus urograndis is quite cultivated in Brazil mainly for adapting to different climatic conditions and being quite resistant to many diseases (Cardoso et al., 2019).

The luminosity of the environment in which the plants grow is of extreme importance for the performance of their vital activities, so that there is an ideal temperature where the plants develop and grow healthier. Otherwise, a discrepant luminosity (high or low, as compared to the ideal one) may hinder or inhibit plant growth (Fonseca, 2019). 
Artificial shading is a widely used practice to control environmental growth-limiting factors, such as luminosity and temperature, which severely affect seedling growth and development (Caron et al., 2010). Environmental conditions can be altered by shading screens (humidity, shading/light, temperature), which provide physical protection to the seedlings by increasing the relative proportion of diffused light in the environment and absorbing/reflecting spectral bands. This alters thus the overall quality of the light (Saraiva et al., 2014).

Thus, the wool blanket is a blanket made entirely of polyester, a recyclable material, originated from the recycling of pet bottles and plays a great role when used as an undercoating, that forms a barrier to prevent the passage of heat and improve the thermal comfort of the environment where it is used (Trisoft, 2018).

In this sense, it is of utmost importance to establish measures to understand the circumstances regarding the growth of quality seedlings under different light intensities, sizes of containers, and inputs. Understand the origin, customs, and morphological changes of seedlings is extremely important to assist reforestation programs and constant growth in the field (Butzke et al., 2018).

The present study aimed to test and identify the best condition for the development of the species in which the species Schizolobium parahyba var. amazonicum and the hybrid Eucalyptus urograndis, to obtain more rustic seedlings with higher quality. For this, it is intended to verify which level of shading better reflects in the best growth of Schizolobium parahyba var. amazonicum and Eucalyptus urograndis, observing which of the two varieties acclimatize better to the established luminosity conditions.

\section{MATERIALS AND METHODS}

\subsection{Description of the area of study}

The experiment was carried out in the greenhouse of the Universidade Federal do Tocantins, at the Gurupi campus, from July to September 2019. Experimental area altitude is $287 \mathrm{~m}$, according to the geographical coordinates: latitude $11^{\circ} 43^{\prime} 45^{\prime \prime} \mathrm{S}$ and longitude $49^{\circ} 04^{\prime} 07^{\prime \prime}$ 'W. Based on Köppen's classification, the region's climate type is AW, defined as humid tropical, with average annual precipitation between $1,500 \mathrm{~mm}$ and $1,600 \mathrm{~mm}$, and average temperature along the year between $22^{\circ} \mathrm{C}$ and $28^{\circ} \mathrm{C}$ (Fonseca et al., 2017).

\subsection{Seedling production and experiment conduction}

Schizolobium parahyba var. amazonicum seeds were purchased at Arbocenter. Eucalyptus urograndis was accomplished by seedlings already formed at the Environmental Nursery Roots Plant. The seeds of Schizolobium parahyba var. amazonicum were covered with an abrasive surface sandpaper (only the opposite side of the hilum was carefully scarified, to do not damage the seed and compromise its germination behavior).

The seeds were sown in a $25 \times 30 \mathrm{~cm}$ polyethylene bag containing substrate composed of the following materials: black soil, bovine manure, and in natura rice straw. In each container, two seeds were sown to ensure maximum germination. Seedlings of Eucalyptus urograndis were placed in the same container as the seeds of Schizolobium parahyba var. amazonicum for 30 days. Seeds of both Schizolobium parahyba var. amazonicum and Eucalyptus urograndis seedlings remained in a greenhouse under $50 \%$ of light restriction arranged on a bench $1 \mathrm{~m}$ high from the ground. They received two daily irrigations before being placed in assay conditions to start the assessment.

At 30 days after the transplant, thinning procedure was carried for seedlings of Schizolobium parahyba var. amazonicum, by leaving only one seedling per container. The most vigorous seedlings were selected. Subsequently, the seedlings were arranged in the following treatments: T1 (full sun), T2 (50\%-shading screen), T3 (plastic), T4 (50\%-shading screen and wool blanket). In treatment $\mathrm{T} 4$ the shade cloth sat on the pet wool, forming a double layer of protection from sunlight.

\subsection{Experimental design}

A completely randomized design carried out, in a $2 \times 4$ factorial scheme, being two species and four levels of shading, and consisted of 5 repetitions and 6 plants per repetition, with a total of 30 seedlings per treatment.

\subsection{Performed analysis}

The morphological and physiological analysis was performed at 60 days after pricking for both species. For these analysis, height $(\mathrm{H})$, from the surface of the substrate to the top of the seedling, stem diameter (SD), and number of leaves (LN) of all plants were measured in each environment.

After assessing the last stem diameter and height of the seedlings (60 DAS), leaf area (LA) was calculated by using contrast algorithms and mathematical models coupled to the ImageJ software version 1.48. Leaves were removed from one plant by repetition and placed on a white sheet size A1 previously identified. The delimited area for software calibration was $3 \times 15$ $\mathrm{cm}\left(45 \mathrm{~cm}^{2}\right)$. Then, all leaves were digitalized by a digital camera of 8.0 megapixels of resolution to obtain the relationship between length, width and leaf area into ImageJ program. 
From these data, plant area (PA), specific leaf area (SLA) and total leaf area (TLA) and leaf area ratio (LAR) were evaluated. The leaf area index (LAI) was assessed according to Lucchesi (1984), based on the following equation:

$\mathrm{LA} / \mathrm{S}$ where:

$\mathrm{LA}=$ leaf area, in $\mathrm{dm}^{2}$

$\mathrm{S}=$ area of available soil, in $\mathrm{dm}^{2}$

\subsection{Physiological analysis}

The analysis of gas exchange parameters and chlorophyll fluorescence were carried out by using a portable Infrared Gas Analyzer - IRGA, LCiSD ADC system ${ }^{\circ}$. Measurements were made on expanded leaves at the first insertion of the primary branch, being measured on the third leaf, from 9 to $12 \mathrm{am}$ on a sunny day. One plant from each repetition was used for random measurements of the following parameters: intercellular $\mathrm{CO}_{2}$ concentration $\left(C_{\mathrm{i}}\right)\left(\mathrm{mmol} \mathrm{m}^{-2} \mathrm{~s}^{-1}\right)$, net photosynthesis rate $(A)\left(\mu \mathrm{mol} \mathrm{CO} \mathrm{m}^{-2} \mathrm{~s}^{-1}\right)$, stomatal conductance $\left(g_{\mathrm{s}}\right)$ $\left(\mathrm{mol} \mathrm{H}_{2} \mathrm{O} \mathrm{m}^{-2} \mathrm{~s}^{-1}\right)$ transpiration $(E)\left(\mathrm{mmol} \mathrm{H}_{2} \mathrm{O} \mathrm{m}^{-2} \mathrm{~s}^{-1}\right)$, and water use efficiency (WUE).

\subsection{Quantification of carotenoids, chlorophyll $a$ and $b$ and total chlorophyll}

After weighing $0.200 \mathrm{~g}$ of leaflets from each seedling, they were kept in a $15 \mathrm{ml}$ tube covered with aluminum foil. 10 $\mathrm{ml}$ of $80 \%$ acetone was added to each tube, where the leaves were macerated and then placed in a thermal box with ice under green light for $48 \mathrm{~h}$. The quantification was performed in a glass cuvette with a white sample containing only $80 \%$ acetone or tissue samples. The reading was performed with a spectrophotometer at absorbances 663,646 and 470 .

The following formulas were used:

$$
\begin{aligned}
& \text { Chla }=12,25^{\star} \mathrm{A} 663-2,79^{\star} \mathrm{A} 646 \\
& \text { Chlb }=21,50^{\star} \mathrm{A} 646-5,10^{\star} \mathrm{A} 663 \\
& \text { Carot }=\left(1000^{\star} \mathrm{A} 470-\left(1,82^{\star} \text { Chla }-104,96^{\star} \text { Chlb }\right)\right) / 198 \\
& \text { Chltotal }=\text { Chla }+ \text { Chlb } \\
& \text { Chl a/b }=\text { Chla } / \text { Chlb } \\
& \text { Chl/carot }=\text { Chl.total } / \text { Carot }
\end{aligned}
$$

Where: Chla, chlorophyll $a$; Chlb, chlorophyll $b$, Carot., carotenoids; Chl. total, sum of the content of chlorophylls $a$ and $b$; Chl $a / b$, chlorophyll a: chlorophyll $b$ ratio; $\mathrm{Chl} /$ carot, total chlorophyll: carotenoids ratio. A663, value of absorbance reading at $663 \mathrm{~nm}$; A646, value of absorbance reading at $646 \mathrm{~nm}$; and A470, value of absorbance reading at $470 \mathrm{~nm}$.

\subsection{Biomass quantification}

To determine biomass parameters, seedlings were collected and washed over sieves. Then, they were packed in Kraft paper bags and placed in a forced ventilation oven at $70^{\circ} \mathrm{C}$, for 72 $\mathrm{h}$ to assess stem dry mass (STDM), leaf dry mass (LDM), root dry mass (RDM), shoot dry mass (SDM), total dry mass (TDM) (Lopes and Lima, 2015). Based on these indicators, height: shoot dry mass ratio (H/SDM) and shoot:root dry mass ratio (SDM/RDM) were calculated.

\subsection{Development analysis}

The Development Quality Index (DQI) was calculated according to the methodology of Dickson et al. (1960), based on the following formula:

$$
\mathrm{DQI}=\frac{\mathrm{TDW}(\mathrm{g})}{\mathrm{H}(\mathrm{cm}) / \mathrm{SD}(\mathrm{mm}) / \mathrm{SDW}(\mathrm{g}) / \mathrm{RDW}(\mathrm{g})}
$$

Where:

TDM = Total dry mass $(\mathrm{g}), \mathrm{H}=$ plant height $(\mathrm{cm}), \mathrm{SD}=$ stem diameter $(\mathrm{mm}), \mathrm{SDM}=$ shoot dry mass $(\mathrm{g})$ and RDM $=$ root dry mass $(\mathrm{g})$.

The data were submitted to analysis of variance and the means compared by Tukey's T-test, at a 5\% probability level using the $\mathrm{R}$ version 3.6.2 program (R Core Team, 2019).

\section{RESULTS AND DISCUSSION}

Among the analyzed variables, only six were statistically significant $(P<0.05)$ for interaction, as follows: height: stem diameter ratio (H/SD), shoot and shoot dry mass ratio (SDM/ $\mathrm{RDM})$, leaf area ratio (LAR), internal carbon $\left(C_{\mathrm{i}}\right)$, chlorophyll $a$ and $b$ ratio (Chl. $a / b)$ and total chlorophyll: carotenoids ratio (Chl.T/carot.) (Table 1) and (Table 2).

To Eucalyptus urograndis, the treatment with a 50\%-shading screen plus wool blanket showed better results in most of the variables, such as $\mathrm{H} / \mathrm{SD}, \mathrm{SDM} / \mathrm{RDM}$ and $C_{\mathrm{i}}$, even presenting similar values statistically. On the other hand, Schizolobium parahyba var. amazonicum also showed better results in the treatment with $50 \%$-shading together plus wool blanket. 
Table 1. Data regarding seedling height evaluations (H), stem diameter (SD), height: stem diameter ratio (H/SD), height: shoot dry mass ratio (H/SDM), stem dry mass (STDM), root dry mass (RDM), leaf dry mass (LDM), shoot dry mass (SDM), total dry mass (TDM), shoot and root dry mass ratio (SDM/RDM), seedling quality index (SQI), plant area (PA), number of leaves (LN), total leaf area (TLA), leaf area index (LAI), leaf area ratio (LAR) in Schizolobium parahyba var seedlings. amazonicum and Eucalyptus urograndis under different levels of shading.

\begin{tabular}{|c|c|c|c|c|c|c|}
\hline \multirow[t]{3}{*}{ Variables } & Shading (S) & Species $(E)$ & SxE & Residue & \multirow{3}{*}{$\begin{array}{l}\text { Average } \\
\text { General }\end{array}$} & \multirow{3}{*}{$\begin{array}{l}\text { C.V } \\
(\%)\end{array}$} \\
\hline & \multicolumn{4}{|c|}{ Degrees of freedom } & & \\
\hline & 3 & 1 & 3 & 32 & & \\
\hline $\mathrm{H}$ & $347.5^{\star}$ & $3540^{*}$ & $159.9 \mathrm{~ns}$ & 80.4 & 56.17 & 15.59 \\
\hline $\mathrm{SD}$ & $0.69 \mathrm{~ns}$ & $0.096 \mathrm{~ns}$ & $1.71 \mathrm{~ns}$ & 0.6 & 5.49 & 14.21 \\
\hline $\mathrm{H} / \mathrm{SD}$ & $11.16^{*}$ & $126.55^{\star}$ & $7.09^{*}$ & 2.32 & 10.35 & 14.36 \\
\hline $\mathrm{H} / \mathrm{SDM}$ & $134.98^{\star}$ & $72.11 \mathrm{~ns}$ & $34.51 \mathrm{~ns}$ & 79.12 & 26.43 & 35.66 \\
\hline STDM & $0.42^{\star}$ & $10.35^{\star}$ & $0.17 \mathrm{~ns}$ & 0.12 & 1.23 & 26.38 \\
\hline $\mathrm{RDM}$ & $0.61^{*}$ & $5.01^{*}$ & $0.015 \mathrm{~ns}$ & 0.1 & 1.11 & 27.56 \\
\hline LDM & $0.69^{*}$ & $0.054 \mathrm{~ns}$ & $0.04 \mathrm{~ns}$ & 0.11 & 1.16 & 27.39 \\
\hline SDM & $1.91^{\star}$ & $8.89^{\star}$ & $0.30 \mathrm{~ns}$ & 0.41 & 2.39 & 25.33 \\
\hline TDM & $3.99^{\star}$ & $27.30^{\star}$ & $0.25 \mathrm{~ns}$ & 0.88 & 3.51 & 25.38 \\
\hline $\mathrm{SDM} / \mathrm{RDM}$ & $2.11^{*}$ & $4.62^{\star}$ & $0.43^{\star}$ & 0.09 & 2.31 & 13.15 \\
\hline SQI & $0.033^{*}$ & $0.032 \mathrm{~ns}$ & $0.007 \mathrm{~ns}$ & 0.009 & 0.28 & 33.65 \\
\hline $\mathrm{AP}$ & $2556.4^{*}$ & $14249.5^{\star}$ & $631.10 \mathrm{~ns}$ & 765.4 & 62.66 & 43.43 \\
\hline NF & $554.3 \mathrm{~ns}$ & $17015.6^{*}$ & $569.40 \mathrm{~ns}$ & 235 & 23.53 & 59.24 \\
\hline AFT & $98558 \mathrm{~ns}$ & $2551 \mathrm{~ns}$ & $159173 \mathrm{~ns}$ & 74266 & 512.07 & 52.88 \\
\hline IAF & $9.32 \mathrm{~ns}$ & $356.11^{\star}$ & $67.78 \mathrm{~ns}$ & 40.2 & 9.97 & 63.42 \\
\hline RAF & $37699^{\star}$ & $74655^{\star}$ & $43248^{\star}$ & 8440 & 171.18 & 57.95 \\
\hline
\end{tabular}

CV: Coefficient of variation. ${ }^{*}$ significant at the $5 \%$ probability level $(0.01 \leq \mathrm{p}<0.05)$; ns: not significant $(\mathrm{p} \geq 0.05)$ by F test.

Table 2. Data regarding the mean of variables: height: stem diameter ratio (H/SD), shoot and root fresh mass ratio (SFM/RFM), shoot and root dry mass ratio (SDM/MSR), leaf area ratio (LAR), internal carbon $\left(C_{\mathrm{i}}\right)$, chlorophyll $a$ and $b$ (Chl. $\left.a / b\right)$ and total chlorophyll: carotenoids ratio (Chl.T/carot.) in Schizolobium parahyba var. amazonicum and Eucalyptus urograndis seedlings under different shading levels.

\begin{tabular}{|c|c|c|c|c|c|c|c|c|}
\hline \multicolumn{9}{|c|}{ Treatments } \\
\hline \multicolumn{6}{|c|}{ Eucalyptus urograndis } & \multicolumn{3}{|c|}{ Schizolobium parahyba var. amazonicum } \\
\hline Variables & $\mathbf{0} \%$ & $50 \%$ & Plastic & $50 \%+$ pet wool & $0 \%$ & $50 \%$ & Plastic & $50 \%+$ pet wool \\
\hline $\mathrm{H} / \mathrm{SD}$ & $11.87 \mathrm{a}$ & $12.30 \mathrm{a}$ & $12.15 \mathrm{a}$ & $13.23 \mathrm{a}$ & $8.15 b c$ & $10.96 \mathrm{a}$ & $6.71 \mathrm{c}$ & $9.5 \mathrm{ab}$ \\
\hline SDM/RDM & $1.65 b$ & $1.96 \mathrm{ab}$ & $1.89 \mathrm{~b}$ & $2.43 \mathrm{a}$ & $2.22 \mathrm{~b}$ & $3.04 \mathrm{a}$ & $2.03 \mathrm{~b}$ & $3.35 \mathrm{a}$ \\
\hline LAR & $117.12 \mathrm{a}$ & $85.62 \mathrm{a}$ & $155.32 \mathrm{a}$ & $103.21 \mathrm{a}$ & $102.37 \mathrm{~b}$ & $145.63 b$ & $177.36 \mathrm{~b}$ & $381.51 \mathrm{a}$ \\
\hline$C_{\mathrm{I}}$ & $275.88 \mathrm{a}$ & $284.06 \mathrm{a}$ & $293.54 \mathrm{a}$ & $312.33 \mathrm{a}$ & $296.27 \mathrm{ab}$ & $327.36 \mathrm{a}$ & $281.89 \mathrm{ab}$ & $251.09 \mathrm{~b}$ \\
\hline Chl. $a / b$ & $37.74 \mathrm{a}$ & $41.1 \mathrm{a}$ & $43.75 a$ & $42.06 \mathrm{a}$ & $28.9 \mathrm{bc}$ & $33.93 \mathrm{ab}$ & $26.23 c$ & $36.28 \mathrm{a}$ \\
\hline Chl. T/carot & $33.87 \mathrm{a}$ & $36.52 \mathrm{a}$ & $36.23 \mathrm{a}$ & $36.14 \mathrm{a}$ & $32.56 \mathrm{ab}$ & $32.26 \mathrm{ab}$ & $29.86 \mathrm{~b}$ & $34.33 \mathrm{a}$ \\
\hline
\end{tabular}

Averages followed by the same letters do not differ from each other by the Tukey $5 \%$ probability test.

For H/SD, Eucalyptus urograndis showed better results under $50 \%$-shading screen plus pet wool; despite they do not vary statistically among them. Otherwise, Schizolobium parahyba var. amazonicum presented better results and differentiated statistically under 50\%-shading screen (Figure 1).

Santos et al. (2019), worked with Enterolobium contortisiliquum (Vell.) Morong seedlings at different shading levels $(0,30,50$ and $70 \%$ ), and found that the shaded environment offered better results, which corroborates with the results found in the present study. Câmara and Endres (2008), worked with Mimosa caesalpiniifolia Benth and Sterculia foetida L. seedlings, and observed higher values under shaded environments when compared to full sun as control.

The $\mathrm{H} / \mathrm{ND}$ ratio is applied to identify seedling quality, since plants that have a low-stem diameter present more difficult to remain erect after planting. Thus, a good relationship between these parameters shows a better development after planting and a likely higher survival rate in the field (Viana et al., 2008).

The SDM/RDM variables showed high values and significant differences in treatment under $50 \%$-shading screen + pet wool, both for Eucalyptus urograndis and Schizolobium parahyba var. amazonicum (Figure 2). 
Figure 1. Effect of shading levels on height and stem diameter of both Eucalyptus urograndis and Schizolobium parahyba var. amazonicum seedlings growing under full sun, 50\%-shading screen, transparent plastic, and 50\%-shading screen plus wool blanket.

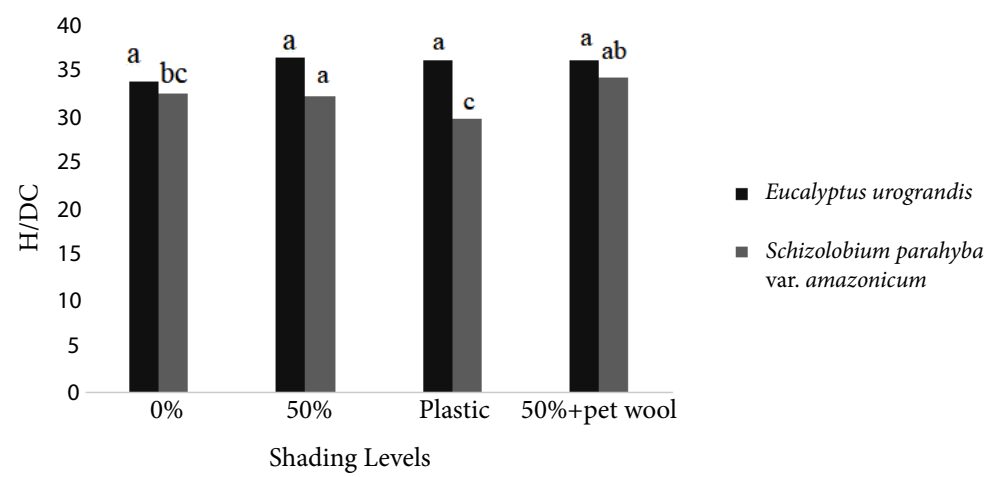

Figure 2. Effect of different shading levels on Eucalyptus urograndis and Schizolobium parahyba var. amazonicum seedlings growing under full sun, 50\%-shading screen, transparent plastic, and 50\%-shading screen plus wool blanket.

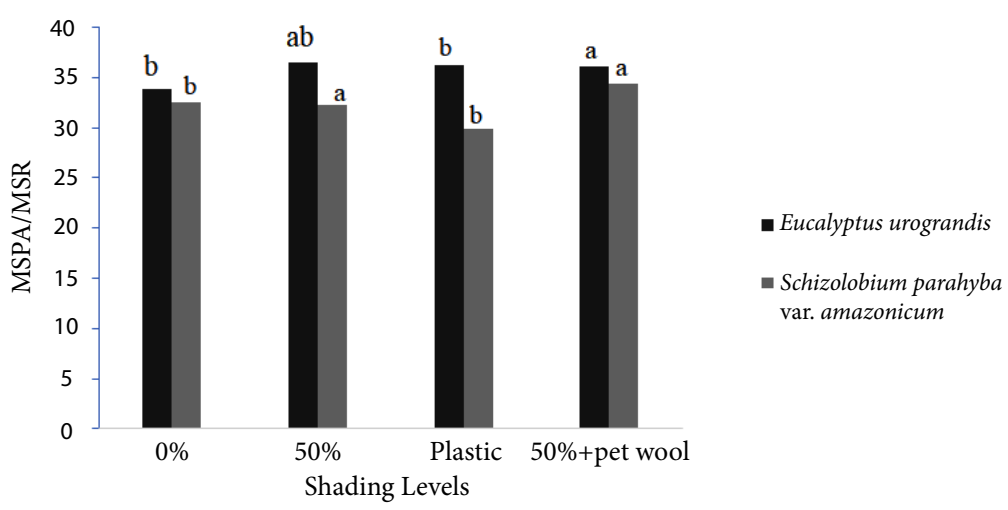

Santos et al. (2019), worked with Enterolobium contortisiliquum (Vell.) Morong seedlings at different shading levels $(0,30,50$, and $70 \%)$, and observed results similar to those found in the present study. For instance, it was observed increases in SDM/RDM as a function of luminosity intensities levels (Figure 7). In accordance with the same author, this result is consistent with the fact that the seedlings present allocate more biomass in the shoot than in the root system, which is a strategy of some species to minimize light competition.

Regarding LAR results, there was no significant difference for Eucalyptus urograndis, however, it is worth mentioning that the treatment with plastic provided the best result. For Schizolobium parahyba var. amazonicum, the best results were observed in treatment with a 50\%-shading screen plus pet wool blanket (Figure 3).

Figure 3. Effect of different shading levels on leaf area ratio (LAR) of Eucalyptus urograndis and Schizolobium parahyba var. amazonicum seedlings growing under full sun, 50\%-shading screen, transparent plastic, and 50\%-shading screen plus wool blanket.

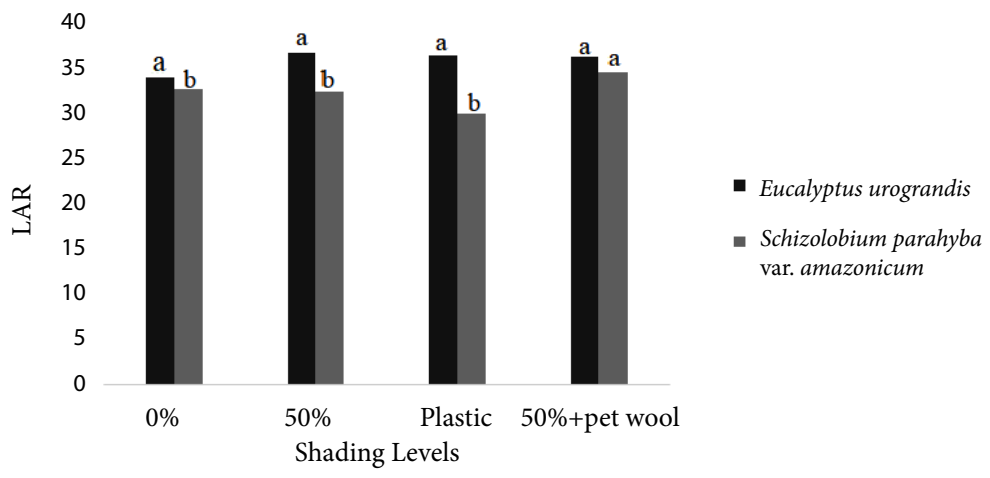


Guimarães (2015), evaluated Schizolobium parahyba var. amazonicum under shading levels at 0,58 and $87 \%$, demonstrated that higher shading levels led to a higher LAR, both in places with low and high atmospheric demand. In accordance with Benincasa (2003), the LAR decreases according to increases in solar irradiance, since the higher the intensity of solar irradiance, the smaller is the foliar area essential to produce biomass.

No significant difference for the internal $\mathrm{CO}_{2}$ concentration $\left(C_{\mathrm{i}}\right)$ in Eucalyptus urograndis was observed; however, for Schizolobium parahyba var. amazonicum, the treatment containing 50\%-shading screen presenting the best results with significant differences (Figure 4).

Saraiva et al. (2014), studied seedlings of Calophyllum brasiliense (Vela) Diaz under different shading levels (0 and 50\%), and evidenced similar results to those observed in this study, e.g., better results in the treatment with $50 \%$-shading screen.

Guerra et al. (2017) concluded that shading screens decrease the harmful effects of both solar radiation incidence and temperature in the plant. In this sense, it seems that the reductions in internal $\mathrm{CO}_{2}$ concentration observed under different shading levels are due to a decrease in radiation intensity on the seedlings, thereby an increase in the $\mathrm{CO}_{2}$ fixation reaction efficiency and consequently a higher photosynthetic rate and enhanced biomass.

The results obtained for the variable Chl. $a / b$ did not present a significant difference for Eucalyptus urograndis; however, there was an expressive difference for Schizolobium parahyba var. amazonicum, in a manner that the treatment with a $50 \%$-shading screen plus wool blanket obtained better results (Figure 5).

In agreement Albuquerque et al. (2015), in their work with Bertholletia excelsa seedlings in full sun, gray canvas, $25 \%$, $50 \%$ and $75 \%$ shading, found similar results corroborating the present study (Figure 6). However, when (Lima et al., 2010) worked with seedlings of Hymenaea courbaril (Ducke) \& Langenh and Enterolobium contortisiliquum (Vell.) Morong, they found opposite results to the present study, in which the chlorophyll $\mathrm{a} / \mathrm{b}$ ratio decreased according to the increased shading level. Thus, one of the attributes of plants exposed to the sun is to manifest a lower amount of chlorophyll molecules by chloroplast, especially chlorophyll b, because these plants do not need to invest in the manufacture of pigments that collect light energy, in a place full of light (TAIZ; ZEIGER, 2010).

Figure 4. Effect of different shading levels on internal carbon of Eucalyptus urograndis and Schizolobium parahyba var. amazonicum seedlings grown under full sun, 50\%-shading screen, transparent plastic, and 50\%-shading screen plus wool blanket.

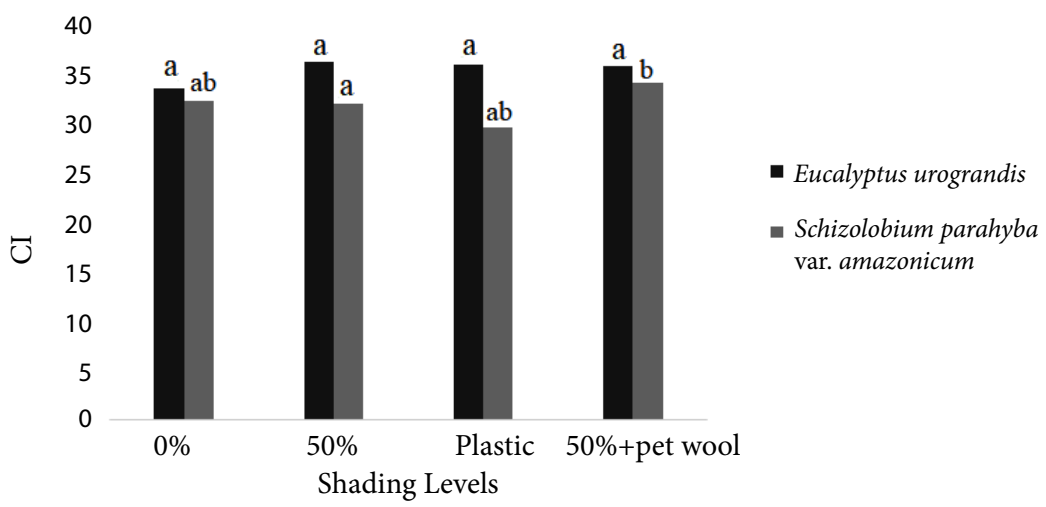

Figure 5. Effect of different shading levels on chlorophyll $a / b$ ratio of Eucalyptus urograndis and Schizolobium parahyba var. amazonicum seedlings grown under full sun, 50\%-shading screen, transparent plastic, and 50\%-shading screen plus wool blanket.

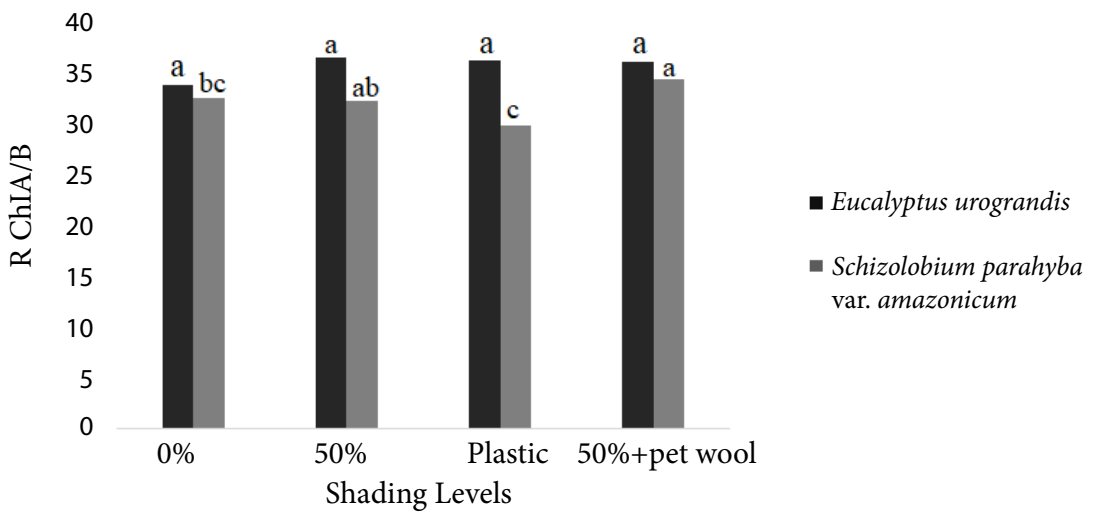


For variable total chlorophyll/carotenoids ratio there was no significant difference for Eucalyptus urograndis, however, for Schizolobium parahyba var. amazonicum there was a significant difference, it is worth noting that the $50 \%$ shading treatment together with the wool blanket showed better results.

Portela (2012), by assessing seedlings of Cariniana strellensis (Raddi.) Kuntze and Cariniana legalis (Mart.) Kuntze under 30-shading screen or full sun, observed similar results to those demonstrated in the present study, in which the shaded environment showed better results for both species. Favaretto et al. (2011), states that the decrease in total chlorophyll/carotenoids ratio in consequence of a high incidence of radiation is explained by the reduction of total chlorophyll content in concomitant to the increase in carotenoids levels.

Among the variables evaluated, Chl. $a$, Chl. $b$, Chl. $T$, carotenoids, it was observed that only Chl. $a / b$ and $\mathrm{Chl} . \mathrm{T} /$ Carot. showed significant difference. The remained variables did not differ statistically (Table 3 )

Figure 6. Effect of different shading levels on total chlorophyll/carotenoid ratio (Chl. T/carot.) of Eucalyptus urograndis and Schizolobium parahyba var. amazonicum seedlings grown under full sun, 50\%-shading screen, transparent plastic, and 50\%-shading screen plus wool blanket.

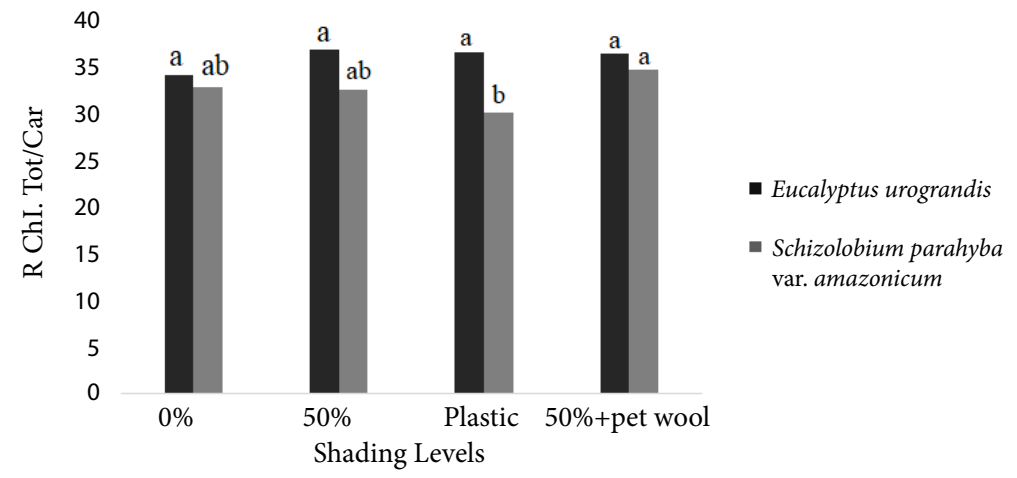

Table 3. Data regarding the evaluations of Chl. $a$, Chl. $b$, Chl. $a /$, Chl. T, carot., Chl. T/carot.

\begin{tabular}{|c|c|c|c|c|c|c|}
\hline \multirow[t]{3}{*}{ Variables } & Shadow(S) & Species(E) & SxE & Residue & \multirow{3}{*}{$\begin{array}{l}\text { Average } \\
\text { General }\end{array}$} & \multirow{3}{*}{$\begin{array}{l}\text { C.V } \\
\text { (\%) }\end{array}$} \\
\hline & \multicolumn{4}{|c|}{ Degrees of freedom } & & \\
\hline & 3 & 1 & 3 & 32 & & \\
\hline Chl. $a$ & $16238.5 \mathrm{~ns}$ & 1393.,4ns & $13865,4 \mathrm{~ns}$ & 6979.6 & 333.43 & 24.66 \\
\hline Chl. $b$ & $5905 \mathrm{~ns}$ & $51473^{*}$ & $9592 n s$ & 3655 & 162.36 & 36.52 \\
\hline Chl. $a / b$ & $67.64^{*}$ & $965.70^{*}$ & $69.75^{*}$ & 17.91 & 36.2 & 11.67 \\
\hline Chl. T & $32686 n s$ & $118976^{*}$ & 43910ns & 19486 & 495.79 & 27.68 \\
\hline Carot. & $8309 \mathrm{~ns}$ & $68500^{*}$ & $13846 \mathrm{~ns}$ & 5799 & 248.09 & 30.32 \\
\hline Chl. T/carot. & $10.68^{*}$ & $118.19^{*}$ & $13.67^{\star}$ & 2.63 & 33.73 & 4.77 \\
\hline
\end{tabular}

C.V: Coefficient of Variation. ${ }^{*}$ significant at the $5 \%$ probability level $(0.01 \leq \mathrm{p}<0.05)$; ns: not significant $(\mathrm{p} \geq 0.05)$ by F test.

The ability of some species to grow quickly under shading is an important mechanism of adaptation. It consists of an indispensable strategy to overcome the conditions of low light intensity. In this vein, plasticity is a characteristic that stands out in some plants under stress situations, making it feasible for biochemical and morpho anatomical modifications to compensate for the adverse conditions in the field. Hence, they modify phytochrome, chlorophylls, carotenoids, anthocyanins contents, as well as alter certain foliar anatomical structures to adapt to new environmental conditions (MORAES NETO et al., 2000; ALBUQUERQUE et al., 2015).

The transpiration $(E)$, stomatal conductance $\left(g_{s}\right)$, net photosynthesis $(A)$, photosynthesis: transpiration ratio $(A / E)$, photosynthesis: stomatal conductance ratio $(A / g)$, photosynthesis: internal carbon ratio $\left(A / C_{\mathrm{i}}\right)$ did not differ statistically between treatments, except internal carbon $\left(C_{\mathrm{i}}\right)$ (Table 4$)$. 
Table 4. Data regarding the evaluations of internal carbon $\left(C_{\mathrm{i}}\right)$, transpiration $(E)$, stomatal conductance $\left(g_{\mathrm{s}}\right)$, net photosynthesis $(A)$, net photosynthesis: transpiration ratio $(A / E)$, liquid photosynthesis: stomatal conductance ratio $\left(A / g_{\mathrm{s}}\right)$, net photosynthesis/internal carbon ratio $\left(A / C_{\mathrm{i}}\right)$

\begin{tabular}{|c|c|c|c|c|c|c|}
\hline \multirow[t]{3}{*}{ Variables } & Shading (S) & Species(E) & SxE & Residue & \multirow{3}{*}{$\begin{array}{l}\text { Average } \\
\text { General } \\
\end{array}$} & \multirow{3}{*}{$\begin{array}{l}\text { C.V } \\
(\%) \\
\end{array}$} \\
\hline & \multicolumn{4}{|c|}{ Degrees of freedom } & & \\
\hline & 3 & 1 & 3 & 32 & & \\
\hline $\mathrm{Ci}$ & $1117.7 \mathrm{~ns}$ & $52.5 \mathrm{~ns}$ & $5132.6^{*}$ & 1566 & 291.41 & 13.63 \\
\hline$E$ & $4.17 \mathrm{~ns}$ & $31.70 \mathrm{~ns}$ & $20.61 \mathrm{~ns}$ & 14.07 & 4.63 & 88.55 \\
\hline$g_{\mathrm{s}}$ & $0.0026 \mathrm{~ns}$ & $0.0036 \mathrm{~ns}$ & $0.0081 \mathrm{~ns}$ & 0.0054 & 0.08 & 98.32 \\
\hline$A$ & $4.23 \mathrm{~ns}$ & $9.49 \mathrm{~ns}$ & $29.24 \mathrm{~ns}$ & 25.67 & 4.38 & 11.16 \\
\hline$A / E$ & $0.20 \mathrm{~ns}$ & $0.00001 \mathrm{~ns}$ & $0.36 \mathrm{~ns}$ & 0.29 & 0.92 & 56.45 \\
\hline$A / g_{\mathrm{s}}$ & $246.21 \mathrm{~ns}$ & $885.2 \mathrm{~ns}$ & $2655.52 \mathrm{~ns}$ & 1148.98 & 57.5 & 57.07 \\
\hline$A / C_{\mathrm{i}}$ & $0.000073 \mathrm{~ns}$ & $0.00016 \mathrm{~ns}$ & $0.000646 \mathrm{~ns}$ & 0.00045 & 0.02 & 133.68 \\
\hline
\end{tabular}

CV: Coefficient of Variation. ${ }^{*}$ significant at the $5 \%$ probability level $(0.01 \leq \mathrm{p}<0.05)$; ns: not significant $(\mathrm{p} \geq 0.05)$ by $\mathrm{F}$ test.

In places of high temperature and luminosity, shading screens may alleviate the extreme effects of radiation, especially photorespiration, thereby contributing to a higher productivity (Silva, 1998).

The stomatal adjustment is an important mechanism capable to reduce water loss from the plant (Albuquerque et al., 2013). This adjustment is evidenced by the partial closure of the stomata under high environmental pressure. This usually occurs around midday, providing a decrease in effective demand for transpiration, increasing the water use efficiency, thereby maintaining the soil moisture (Yang, 2012).

\section{CONCLUSIONS}

It is concluded that the different levels of shading $(0 \%$; 50\%; plastic; $50 \%+$ pet wool) affect significantly height: stem diameter ratio (H/ND), shoot and root dry mass ratio (SDM/ $\mathrm{RDM})$, leaf area ratio (LAR), internal carbon (Ci), chlorophyll $a$ and $b$ ratio (Chl. $a / b)$ and total chlorophyll: carotenoids ratio (Chl.T/carot.).

Based on this, it is reasonable to suggest that Eucalyptus urograndis can be produced under full sun, since only one variable obtained a significant difference.

It was verified that Schizolobium parahyba var. amazonicum needs to be produced under a shaded environment ( $50 \%$-shading screen) coupled with a wool blanket, once it obtained better results in most variables and presented a good development under such condition.

New studies are necessary to confirm the efficiency of $50 \%$-shading screen plus wool blanked, to better understand whether these seedlings can be produced with quality under shaded environments on a large scale.

\section{SUBMISSION STATUS}

Received: 29 Jun. 2021

Accepted: 03 Jan. 2022

Associate editor: José Carlos Arthur Junior (1)

\section{CORRESPONDENCE TO}

\section{Hygor Gomes de Almeida Sousa}

Universidade Federal do Tocantins, Rua Badejós, Lote $7 \mathrm{~s} / \mathrm{n}$, Chácaras 69/72, Jardim Sevilha, CEP 77410-530, Gurupi, TO, Brasil. e-mail: hygoralmeida.floresta@outlook.com

\section{AUTHORS' CONTRIBUTIONS}

Hygor Gomes de Almeida Sousa: Project administration (Lead). Igor Viana Souza, Bruno Aurélio Campos Aguiar: Software (Lead). Gabriella Rayssa Antunes da Silva Oliveira: Validation (Lead).

Flávia Bezerra Souza: Investigation (Lead).

Maristela Lima Figueiredo Guimarães Epifânio: Conceptualization (Equal)

Valéria Cardoso Lopes: Writing - review \& editing (Lead).

Priscila Bezerra Souza: Supervision (Lead).

\section{REFERENCES}

Albuquerque MPF, Moraes FKC, Santos RIN, Castro GLS, Ramos EMLS, Pinheiro HA. Ecophysiology of young African mahogany plants submitted to water deficit and rehydration. Brazilian Agricultural Research 2013; 48(1): 9-16.

Albuquerque TCS, Evangelista TC, NETO AARA. Shading levels in the growth of Brazil nut seedlings. Revista Agro@ mbiente Online 2015; 9(4): 440-445.

Bentec. Seeds, Inputs and Technology. [Accessed on June 16, 2020]. Available from: http://www.bentecsementes.com.br/eucaliptourograndis/.

Benincasa MMP. Plant growth analysis (basics). two. ed. Jaboticabal: FUNEP; 2003.

Brazilian Tree Industry. IBÁ: Statistical Yearbook of IBÁ 2019 - base year 2018. Brasília; 2019.

Butzke AG, Miranda EM, Neto RCA, Bianchini F, Fiuza SS. Production of Paricá seedlings (Schizolobium amazonicum Huber ex Ducke) in different types of substrates, containers and shading levels in Rio Branco, Acre. Biosphere Encyclopedia 2018; 15(27): 254-263.

Câmara CA, Endres L. Development of seedlings of two tree species Mimosa caesalpiniifolia Benth. and Sterculia foetida L. under different levels of shade in nursery. Floresta 2008; 38(1): 43-51. 
Cardoso RC, Alcântara AL, Souza FM, Espinheira MJCL. Antimicrobial Potential of Eucalyptus urograndis Leaf Oil Front Stafilococus aureus. Id on Line. Multidisciplinary and Psychology Journal 2019; 13(43): 989-1002.

Caron BO, Souza VQ, Cantarelli EB, Manfron PA, Behling A, Eloy E. Seedling growth of Schizolobium parahyba (Vell.) S. F. Blake, submitted to shade levels. Ciência Florestal 2010; 20(4): 683-689.

Dickson A, Leaf AL, Hosner JF. Quality appraisal of white spruce and white pine seedling stock in nurseries. The Forestry Chronicle 1960; 36(1): 10-13.

Favareto VF, Martinez CA, Soriani HH, Furriel RPM. Differential responses of antioxidant enzymes in pioneer and late-successional tropical tree species grown under sun and shade conditions. Environmental and Experimental Botany 2011; 70(1): 20-28.

Fonseca MDS. Gas exchanges and initial growth of eucalyptus clones under different thermal and water conditions [thesis]. Jerônimo Monteiro: Graduate Program in Forest Sciences at the Center for Agricultural Sciences and Engineering, Federal University of Espirito Santo; 2019.

Guerra AMNM, Costa ACM, Tavares PRF. Photosynthetic activity and yield of lettuce grown under shade. Revista Agropecuária Técnica 2017; 38(3): 125-132.

Guimarães SO. Growth of Schizolobium amazonicum (Huber ex Ducke) under different conditions of shading and atmospheric demand [Dissertation]. Jerônimo Monteiro: Federal University of Espirito Santo; 2015.

Lima ALS, Zanella F, Castro LDM. Growth of Hymenaea courbaril L. var. stilbocarpa (Hayne) Lee et Lang. and Enterolobium contortisiliquum (Vell.) Morong (Leguminosae) under different levels of shading. Amazonian Act 2010; 40(1): 43-48.

Malagi J. Development of Eucalyptus Urograndis planted after using different soil acidity correctives [Completion of course work]. Dois Vizinhos: Federal Technological University of Paraná; 2015.

Moraes Neto SP, Gonçalves JLM, Takaki M, Cenci S, Gonçalves JC. Growth of seedlings of some tree species that occur in the Atlantic Forest, depending on the level of light. Revista Árvore $2000 ; 24(1): 35-45$.
Portela FCS. Influence of luminosity on the physiology and morphology of Jequitibá-branco (Cariniana strellensis (Raddi.) Kuntze) and Jequitibá-rosa (Cariniana legalis (Mart) Kuntze) [Dissertation]. Vitória: Federal University of Espirito Santo; 2012.

R Core Team (2019). A language and environment for statistical computing [ Accessed on July 14, 2020]. Available from: www.Rproject.org/.

Saraiva GR, Souza GM, Rodrigues JD. Acclimation and physiology of guanandi seedlings grown in photo-protective shading screens. Colloquium Agrariae 2014; 10(2): 01-10.

Schizolobium in Flora do Brasil 2020. [Accessed on sep, 2020]. Available from: http://reflora.jbrj.gov.br/reflora/floradobrasil/ FB23142.

Siebeneichler SC, Barbosa JS, Cruz AMM, Ramos MAD, Fernandes HE, Nascimento VL. Comparison between extraction methods of photosynthetic pigments in Acacia mangium. Communications in Plant Sciences 2019; 9(1): 1-5.

Silva VF. Cultivation of lettuce in different spacing under high temperature and brightness [Dissertation]. Mossoró: Federal Rural University of the Semi-Arid; 1998.

Taiz L, Zeiger E. Plant physiology. 4rd ed. Porto Alegre: Artmed; 2010.

Trisoft. [Accessed on Nov, 2020]. Available from: https://www. aecweb.com.br/cls/catalogos/trisoft/catalogo_ isosoft.pdf.

Viana JS, Gonçalves EP, Andrade LA, Oliveira LSB, Silva EO. Seedling growth of Bauhinia forficata Link. in different container sizes. Floresta 2008; 38(4): 663-671.

Vidaurre GB, Carneiro ACO, Vital BR, Santos RC, Valle MLA. Energetic properties of wood and paricá coal (Schizolobium amazonicum). Revista Árvore, Viçosa 2012; 36(2): 365-371.

Xavier G.S. Influence of heat treatments on two mechanical properties of Pinus sp. and Eucalyptus urograndis. [Completion of course work]. Brasília: University of Brasília; 2013.

Yang Z, Sinclair TR, Messina CD, Cooper M, Hammer GL, Zhu $M$. Temperature effect on transpiration response of maize plants to vapor pressure deficit. Environmental and Experimental Botany 2012; 78(1) 157-162. 